\begin{tabular}{|} 
Ambiente \& Água - An Interdisciplinary Journal of Applied Science \\
ISSN 1980-993X - doi:10.4136/1980-993X \\
www.ambi-agua.net \\
E-mail: ambi.agua@gmail.com
\end{tabular}

\title{
Potentially toxic metals in lotic systems with aptitude for aquaculture at the watershed Mantaro River, Peru
}

\author{
ARTICLES doi:10.4136/ambi-agua.2261
}

Received: 27 Mar. 2018; Accepted: 16 Nov. 2018

\author{
María Custodio $^{1 *(D)}$; Fernán Cosme Chanamé Zapata1 ${ }^{1 D}$; \\ Danny Julio Cruz Flores ${ }^{1}{ }^{1}$; Wilfredo Bulege Gutiérrez ${ }^{2}$; \\ ${ }^{1}$ Universidad Nacional del Centro del Peru (UNCP), Huancayo, Junín, Peru \\ Department of Zootecnia. E-mail: mcustodio@uncp.edu.pe, \\ fernan_chz@hotmail.com, cruzfloresdj@gmail.com \\ ${ }^{2}$ Universidad Continental, Huancayo, Junín, Peru \\ Direction of Research. E-mail: wbulege@continental.edu.pe \\ *Corresponding author
}

\begin{abstract}
The objective of the study was to analyze the concentration of $\mathrm{Cu}, \mathrm{Zn}, \mathrm{Fe}, \mathrm{Pb}$ and $\mathrm{As}$ in river water suitable for aquaculture in the watershed of the Mantaro River using multivariate statistical methods, during the period 2011-2013. The determinations of total heavy metals in water collected during two different climatic periods were performed by atomic absorption spectrophotometry, according to the methodology recommended by FAO. The results obtained show that, in the seven rivers evaluated, the average concentration of $\mathrm{Pb}, \mathrm{Fe}$ and $\mathrm{Cu}$ exceeded the quality standards of Peru's continental water for the extraction and cultivation of hydrobiological species and USEPA standards for the protection of fish and aquatic life. The average concentration of $\mathrm{Zn}$ only exceeded USEPA standards. While the concentrations of $\mathrm{Pb}$ and $\mathrm{Cu}$ also surpassed those of the WHO. The cluster analysis suggests that the evaluated rivers, in which fish farming activity is intensively developed, have similar characteristics in relation to the concentration of heavy metals. According to the analysis of main components, in Component 1 , there are moderate loads for arsenic; in Component 2, there is a strong load for zinc and relatively low loads for iron; and, in Component 3, there is a moderate load for iron. The discriminant analysis revealed that two of the five variables were significant predictors of the season; in this case, copper and lead were sufficient to discriminate the variables between the rainy or dry season.
\end{abstract}

Keywords: fit fitness, heavy metals, lotic system.

\section{Metais potencialmente tóxicos em sistemas lóticos com aptidão para a aquicultura na bacia hidrográfica do rio Mantaro, Peru}

\section{RESUMO}

O objetivo do estudo foi analisar as concentrações de $\mathrm{Cu}, \mathrm{Zn}, \mathrm{Fe}, \mathrm{Pb}$ e As em rios de águas com aptidão para a aquicultura na bacia do rio Mantaro utilizando métodos estatísticos multivariados, no período 2011-2013. A determinação do total de metais pesados em água coletada durante dois períodos climáticos contrastantes foi realizada por espectrofotometria de absorção atômica, de acordo com a metodologia recomendada pela FAO. Os resultados obtidos 
mostram que nos sete rios avaliados a concentração média de $\mathrm{Pb}, \mathrm{Fe}$ e $\mathrm{Cu}$ excedeu os padrões de qualidade da água continental do Peru para extração e cultivo de espécies hidrobiológicas e padrões USEPA para a proteção de peixes e vida aquática. A concentração média de Zn excedeu apenas os padrões da USEPA. Enquanto as concentrações de $\mathrm{Pb}$ e Cu também superaram as da OMS. A análise de agrupamento sugere que os rios avaliados, nos quais a atividade pesqueira é intensamente desenvolvida, têm características semelhantes em relação à concentração de metais pesados. De acordo com a análise dos componentes principais, no componente 1, há cargas moderadas para o arsênio; no componente 2, há uma carga forte para o zinco e cargas relativamente baixas para o ferro e, no componente 3 , é uma carga moderada de ferro. A análise discriminante revelou que duas das cinco variáveis foram preditores significativos do tempo, neste caso, cobre e chumbo foram suficientes para discriminar as variáveis entre a estação chuvosa ou a estação seca.

Palavras-chave: fitness de peixes, metais pesados, sistemas lóticos.

\section{INTRODUCTION}

In the last decades, the balance of aquatic ecosystems has been altered by the increase in discharges of wastewater containing organic and inorganic pollutants, highlighting heavy metals among the latter, which, unlike organic pollutants that can be metabolized by aquatic microbiota, are indestructible (Gunatilake, 2015). The contamination generated by these metals due to increasing industrialization represents a special environmental risk due to its persistence in the environment, possible bioaccumulation and biomagnification in the food chain (Kwok et al., 2014).

Some heavy metals, such as copper $(\mathrm{Cu})$, zinc $(\mathrm{Zn})$, cobalt $(\mathrm{Co})$ and iron $(\mathrm{Fe})$, are necessary for life and are only considered a hazard when they exceed the established concentrations (Waseem et al., 2014). Others such as cadmium $(\mathrm{Cd})$, mercury $(\mathrm{Hg})$ and lead $(\mathrm{Pb})$ were discharged into the rivers by various factories and cause undesirable changes in the quality of the environment of these ecosystems, affecting the ecological balance of the aquatic environment and ultimately human beings through the food chain (Chanamé et al., 2017).

Among the aquatic species that are exposed to heavy metals, fish are most commonly affected by these toxic pollutants that exert their action in different organs. Studies conducted to examine the concentration of heavy metals in water and in different fish species at different latitudes have revealed that both essential and non-essential metals can cause biotoxic effects (Kwok et al., 2014). In other studies, the evaluation of heavy metals in different compartments has been complemented with the determination of water quality through water quality indexes and geo-accumulation to indicate the level of contamination by heavy metals presented by sediment samples in the sea and suspension. However, the degree of contamination in the environments and in fish tissues depends on the type of contaminant, the fish species, the sampling site, the trophic level and their mode of feeding (Islam et al., 2015; Kapia et al., 2016).

The vast ocean of the Mantaro River is one of the areas of Peru with great metallurgical, mining and fish-farming activity. Nine decades ago the metallurgical industry began its operation in the circuits $\mathrm{Cu}, \mathrm{Pb}, \mathrm{Zn}, \mathrm{Ag}, \mathrm{Au}, \mathrm{Cd}, \mathrm{In}, \mathrm{Bi}, \mathrm{Sb}, \mathrm{As}, \mathrm{Se}$ and Te. There are also byproducts of these activities, such as sulfuric acid, sodium bisulfate, copper, sulphate, zinc powder, arsenic trioxide and a variety of residues with a high level of toxicity, generating air pollution in La Oroya, one of the most polluted cities in the world, and in contiguous rural areas. This situation has led to backlash against the environmental pollution generated by this industry, leading to the suspension of its operation in 2009. On the other hand, the mining industry through its wastewater discharges is also exerting strong pressure on the water quality and aquatic biodiversity of the hydrographic units that form at the bottom of the Mantaro River, 
therefore reducing the multiple uses of the water. However, in the last decade, many of the lotic systems of this watershed have intensified production of rainbow trout for export purposes.

In this regard, and given the limited information available on the concentration of heavy metals in lotic systems with fish fitness in the bottom of the Mantaro River and the risks that accumulation can represent for the aquatic environment and human health, it is necessary to have information that reveals the level of contamination that these aquatic systems present. The objective of the study was to analyze the concentration of $\mathrm{Cu}, \mathrm{Zn}, \mathrm{Fe}, \mathrm{Pb}$ and $\mathrm{As}$ in rivers water with aptitude for aquaculture in the Mantaro River Basin using multivariate statistical methods, during the period 2011-2013.

\section{METHODS AND RESOURCES}

\subsection{Area of the Study}

The Mantaro River is located in the Central Andes of Peru, between the latitudes of: $10^{\circ} 34^{\prime \prime} \mathrm{S}-13^{\circ} 35^{\prime \prime} \mathrm{S}$ and longitudes: $73^{\circ} 55^{\prime \prime} \mathrm{W}-76^{\circ} 40^{\prime \prime} \mathrm{W}$, with altitudes ranging from 500 masl to 5,350 masl. It covers an area of approximately $34,550 \mathrm{~km}^{2}$, whose flow depends on rainfall, the water level of Lake Junin and the lagoons located at the foot of the mountains in the western and Eastern mountain ranges (Zubieta et al., 2017).

In the Junin region, the tributaries of the Mantaro River with aptitude for aquaculture considered in the study are located in the districts of Paccha and La Oroya of the Yauli Province (Figure 1). In Paccha, the Casaracra and Quinuacocha Rivers are located at 3801 masl $(396041 \mathrm{E}, 8733599 \mathrm{~N})$ and 3670 masl $(399331 \mathrm{E}, 8728673 \mathrm{~N})$, respectively. In La Oroya, Pacchapata Rivers at 4200 masl (401917E, 8726727N), Geshgash at 3900 masl (407442E, 8720525 N), Papahuay at 3920 masl (409690E, 8715795N), Capaco at 3900 masl (412113E, 8714136N) and Paraíso at 3850 masl (409735E, 8713106N).

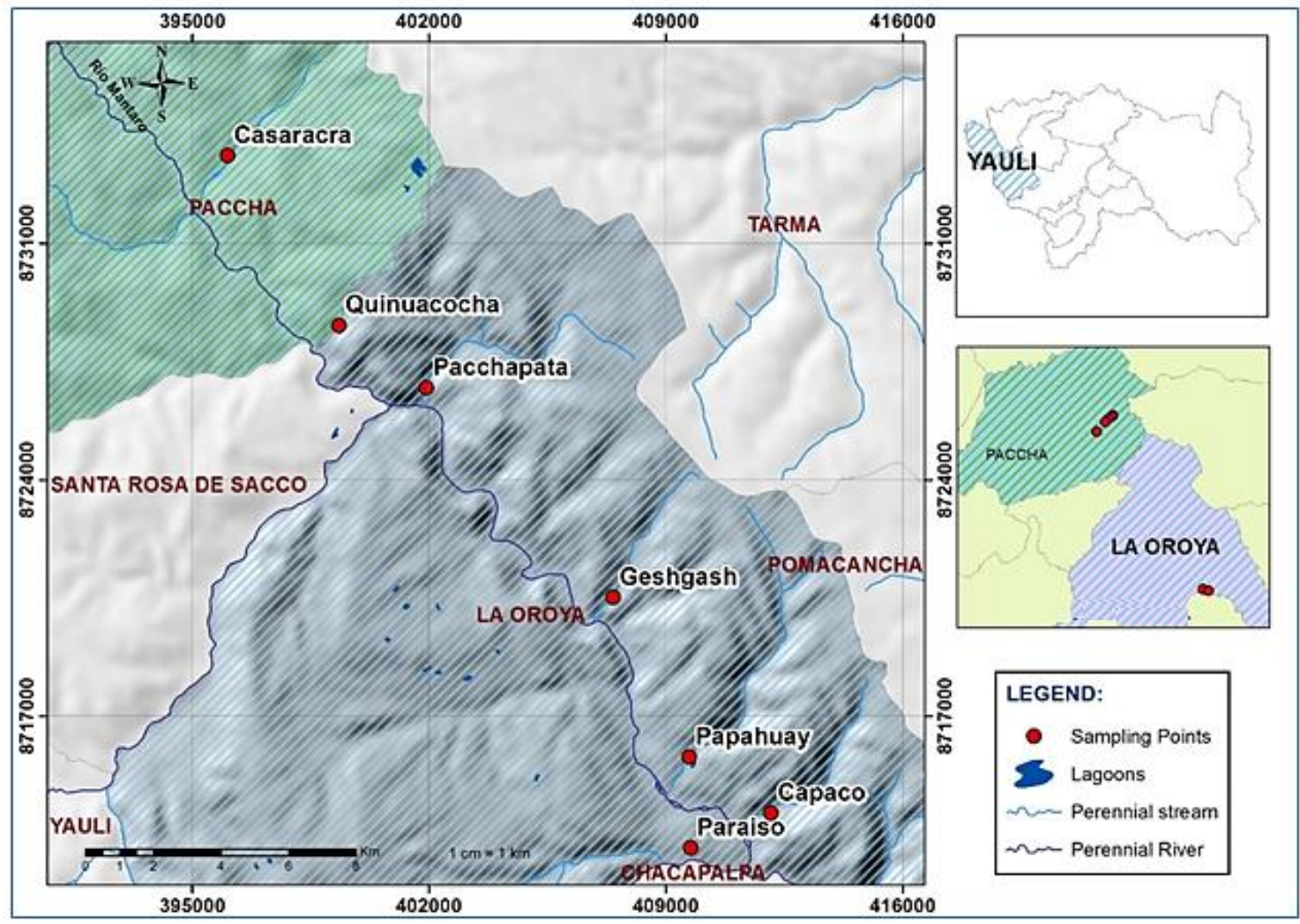

Figure 1. Location of sampling points in lotic systems with aptitude for aquaculture in the Mantaro River watershed. 


\subsection{Obtaining water samples}

The water samples were collected in two stages during the 2011-2013 periods. The first stage corresponded to the rainy season (January, February, March, and April) and, the second stage was during the dry season (May, June, July and August. During both stages, the surface water samples were collected in seven sampling sites, in triplicate (left margin, middle and right bank of the river) in the opposite direction to the flow of the stream at $30 \mathrm{~cm}$ depth, in two-liter plastic bottles, previously treated with a $10 \%$ nitric acid solution for 24 hours and rinsed with bidistilled water. Subsequently, $1.5 \mathrm{ml}$ of concentrated nitric acid was added to one liter of water from each of the samples for its preservation (APHA et al., 2012). For the determination of $\mathrm{BOD}_{5}$, water samples were collected in amber bottles, previously treated with 1:1 hydrochloric acid solution and rinsed with distilled water.

\subsection{Determination of the concentration of heavy metals in water}

The preparation of the sample consisted of placing $250 \mathrm{ml}$ of water in a beaker, which was boiled to obtain $100 \mathrm{ml}$. Immediately, $5 \mathrm{ml}$ of nitric acid and $5 \mathrm{ml}$ of ultra-pure hydrochloric acid (supplied by Merck Germany) were added to achieve complete oxidation and reduce the interference that organic matter could cause. The sample was then boiled again until the water was consumed. The sample was allowed to cool and then $10 \mathrm{ml}$ of distilled water was added, filtered and stocked in a $100 \mathrm{ml}$ vial, with $1 \%$ nitric acid (APHA et al., 2012).

The concentration of copper, zinc, iron, lead and arsenic (mg/L), was determined by the flame atomic absorption spectrophotometry method, according to the methodology recommended by the FAO (Nauen, 1983), using a Shimadzu-brand AA-6800 Atomic Absorption Spectrophotometer.

\subsection{Preparation of the calibration curve}

The standard solutions for $\mathrm{Pb} \mathrm{Cu}, \mathrm{Fe}, \mathrm{Zn}$ and As were supplied by Merck with the highest purity level (99.98\%). With the $1000 \mathrm{ppm}$ standard of $\mathrm{Pb}, \mathrm{Cu}, \mathrm{Fe}, \mathrm{Zn}$ and $\mathrm{As}$, an average standard of $100 \mathrm{ppm}$ concentration was prepared. Then the working standards of $0.001 ; 0.01$; $0.1 ; 1.0$ and $2.0 \mathrm{ppm}$, with $1 \%$ nitric acid. Next, the absorbance readings of the standards were performed at different wavelengths for each element in the atomic absorption spectrophotometer. Finally, the calibration curve was plotted: concentration vs absorbance and the concentration of the samples were read using the respective calibration curve.

\subsection{Determination of fish-fitness indicators}

The indicators of the fish fitness of the lotic systems under study determined in situ were: temperature, dissolved oxygen and $\mathrm{PH}$. Water samples were collected at the site using a water sampler for the detection of each of these indicators and their determination was made using Hanna Instruments portable equipment (HI 991301 Micro pH/ temperature, and HI 9146 Microprocessor dissolved oxygen). Previously, the equipment was calibrated at the respective sampling site. The determination of the $\mathrm{BOD}_{5}$ was made by the respirometric method with the OxiDirect Lovibond equipment.

\subsection{Analysis of data}

The normality and distribution of potentially toxic metals data in waters of rivers with aptitude for fish tributaries of the Mantaro River was analyzed; the data with exponential distributions (copper, iron and zinc) were transformed.

\subsubsection{Cluster Analysis (CA)}

This analysis belongs to the group of multivariate techniques whose purpose is to classify the available information based on certain characteristics they possess with respect to a 
predetermined selection criterion. It is expected that the resulting clusters should show high internal homogeneity (within the group) and high external heterogeneity (between clusters). We used the Ward method (minimum variance) that is within the agglomerative hierarchical approach, this being the most common approach. The dendrogram provides a visual summary of the grouping processes, presenting the groups and their proximities. The euclidean distance usually gives the similarity between two samples and a distance can be represented by the difference between the values of the samples (Everitt, 1980) Equation 1.

$$
d(x, y)=\sqrt{\sum_{i=1}^{p}\left(x_{i}-y_{i}\right)^{2}}
$$

In this study, a agglomerative hierarchical approach, rather than a divisive algorithm, was employed.

\subsubsection{Principal component analysis (PCA)}

PCA transforms the original variables into new, uncorrelated ones, called the principal components, which are linear combinations of the original variables so that the variation of the data can be explained as concisely as possible. The main components provide information on the most significant parameters, in a way that allows reducing the data without losing the original information. The main component can be expressed as Equation 2:

$$
z_{i j}=a_{i 1} x_{1 j}+a_{i 2} x_{2 j}+a_{i 3} x_{3 j}+\ldots+a_{i m} x_{m j}
$$

Where $\mathrm{z}$ is the value of the component, a is the coefficient of the component, $\mathrm{x}$ is the measure value of the variable, $i$ is the component number, $j$ is the number of the simple and $m$ is the total number of variables.

\subsubsection{Discriminant Analysis (DA)}

The discriminant analysis is the statistical method that allows discriminating and classifying the different data in groups. If the discriminant analysis is effective for a data gathering, the estimation classification table produces a high percentage of "correct" and the percentage of these is located on the diagonal of the table. The DA technique creates a discriminant function for each group that operates on data and constructs a discriminant function for each group (Heckler, 2005), as in the following Equation 3:

$$
f\left(G_{i}\right)=k_{i}+\sum_{j=1}^{n} w i_{j} \cdot p_{i j}
$$

Where $\mathbf{i}$ is the number of groups $(\mathrm{G}), \mathbf{k}_{\mathbf{i}}$ is the constant inherent in each group, $\mathbf{n}$ is the number of parameters used to classify a data set in a given group, $\mathbf{w}_{\mathbf{j}}$ is the weight coefficient, assigned by DA to certain selected parameters $\left(\mathbf{p}_{\mathbf{j}}\right)$.

In this study, the DA was performed with original data using the standard, step-by-step and backwards stepwise to evaluate both temporal and spatial variations of water quality. The river sectors and sampling periods were the grouping variables and the measured parameters were the independent variables.

\section{RESULTS AND DISCUSSION}

\subsection{Determination of the aptitude for aquaculture of lotic systems through physical- chemical indicators}

The results of the physical-chemical indicators of the water column of the seven rivers evaluated are presented in Table 1. 
Table 1. Descriptive statistics of physical-chemical indicators of water quality of rivers with aptitude for aquaculture evaluated during 2011-2013, in relation to the national environmental quality standards for water.

\begin{tabular}{|c|c|c|c|c|c|c|c|c|c|}
\hline Indicator & ED & Capaco & Casaracra & Geshgash & Pacchapata & Papahuay & Paraíso & Quinuacocha & MINEN \\
\hline \multirow{3}{*}{$\begin{array}{c}\text { pH } \\
\text { Unit }\end{array}$} & Range & $7.33-8.15$ & $7.22-8.10$ & $7.33-8.25$ & $7.40-8.13$ & $7.18-8.30$ & $7.50-8.30$ & $7.05-8.09$ & $6-9$ \\
\hline & Mean & 7.73 & 7.62 & 7.75 & 7.73 & 7.81 & 7.85 & 7.60 & \\
\hline & S.D & 0.22 & 0.22 & 0.26 & 0.17 & 0.24 & 0.20 & 0.25 & \\
\hline \multirow{3}{*}{$\begin{array}{c}\text { Temperature } \\
{ }^{\circ} \mathrm{C}\end{array}$} & Range & $10.20-11.60$ & $10.55-11.70$ & $10.60-11.75$ & $10.40-11.60$ & $10.50-11.40$ & $10.00-11.60$ & $10.55-11.75$ & $\Delta 3$ \\
\hline & Mean & 10.89 & 11.11 & 11.01 & 11.06 & 11.00 & 10.73 & 11.03 & \\
\hline & S.D & 0.36 & 0.32 & 0.29 & 0.30 & 0.28 & 0.47 & 0.31 & \\
\hline \multirow{3}{*}{$\begin{array}{c}\text { Dissolved Oxygen } \\
\mathrm{mg} / \mathrm{L}\end{array}$} & Range & $7.35-8.30$ & $7.45-8.20$ & $7.50-8.50$ & $7.42-8.23$ & $7.40-8.20$ & $7.25-8.10$ & $7.45-8.50$ & $\geq 5$ \\
\hline & Mean & 7.72 & 7.76 & 7.92 & 7.75 & 7.79 & 7.69 & 7.84 & \\
\hline & S.D & 0.21 & 0.18 & 0.27 & 0.22 & 0.23 & 0.17 & 0.25 & \\
\hline \multirow{3}{*}{$\begin{array}{l}\text { BOD }_{5} \\
\mathrm{mg} / \mathrm{L}\end{array}$} & Range & $7.00-8.00$ & $7.20-8.00$ & $7.00-8.05$ & $7.44-8.30$ & $7.38-8.10$ & $6.82-8.15$ & $7.45-8.05$ & 10 \\
\hline & Mean & 7.61 & 7.65 & 7.68 & 7.71 & 7.71 & 7.56 & 7.68 & \\
\hline & S.D & 0.19 & 0.18 & 0.24 & 0.17 & 0.16 & 0.29 & 0.15 & \\
\hline
\end{tabular}


The physical-chemical indicators of water are very important because they have a significant effect on water quality and aquatic life (Şener et al., 2017). The $\mathrm{pH}$ of the water presented variations with means that oscillated from $7.60 \pm 0.25$ in the Quinuacocha River to $7.85 \pm 0.20$ in the Paraíso River, with a maximum value of 8.30 . These variations would be related to the edaphic conditions through which the water currents pass (Munavalli an Mohan Kumar, 2005). Temperature, as the limiting factor of aquatic life, acquires great importance in the development of the different phenomena that are carried out in the water, since it determines the tendency of its physical properties and the composition of biological communities (Tyagi et al., 2013). The temperature of the water did not present important changes, although there was a slight increase in the Geshgash and Quinuacocha Rivers, with mean values that ranged from $10.73 \pm 0.47^{\circ} \mathrm{C}$ in the Paraiso River to $11.11 \pm 0.32^{\circ} \mathrm{C}$ in the Casaracra River. The indicators of organic matter associated with oxygen consumption in the seven rivers showed a similar behavior. The highest concentrations of dissolved oxygen were recorded in the Geshgash and Quinuacocha Rivers. However, the Geshgash River presented the highest average concentration. These results reveal the good level of oxygenation of the waters of these rivers that, together with the temperature, determine the richness and distribution patterns of the biological communities (Wronski et al., 2015). The mean concentration of $\mathrm{BDO}_{5}$ ranged from $7.56 \pm 0.29 \mathrm{mg} / \mathrm{L}$ in the Paraíso River to $7.71 \pm 0.17 \mathrm{mg} / \mathrm{L}$ in Pacchapata and Papahuay Rivers. All the results obtained from the physical-chemical indicators of water are in the range of environmental quality standards (EQS) for river waters of Peru, category two, subcategory four, referring to the extraction and cultivation of hydrological species in inland waters, and for category four, referring to the conservation of aquatic life.

\subsection{Determination of the concentration of potentially toxic metals in water}

The results of the concentration of potentially toxic metals are shown in Table 2 . The mean concentration of the metals studied followed the decreasing order of $\mathrm{Fe}>\mathrm{Zn}>\mathrm{Pb}>\mathrm{Cu}>\mathrm{As}$. The concentration of arsenic in the evaluated rivers ranged from 0.004 to $0.064 \mathrm{mg} / \mathrm{L}$, with the highest average concentrations being found in the Capaco Rivers $(0.032 \pm 0.009 \mathrm{mg} / \mathrm{L})$ and Paraíso $(0.032 \pm 0.012 \mathrm{mg} / \mathrm{L})$. However, in none of the rivers did the evaluated arsenic concentration exceed the EQS, category tow, subcategory four, referring to the extraction and cultivation of hydrobiological species of Ministry of the Environment (MINEN) (Perú, 2015) nor the standard referring to the protection of freshwater aquatic life of the United States Environmental Protection Agency (USEPA, 2006). The concentration of lead varied from 0.008 to $0.105 \mathrm{mg} / \mathrm{L}$, showing the highest average concentration of lead in the Capaco River $(0.043$ $\pm 0.021 \mathrm{mg} / \mathrm{L})$. In the seven rivers evaluated, the average lead concentration exceeded the national standards of the MINEN $(0.0025 \mathrm{mg} / \mathrm{L})$ and the USEPA limit $(0.01 \mathrm{mg} / \mathrm{L})$ referring to the protection of fish and aquatic life and the threshold level set by WHO $(0.003 \mathrm{mg} / \mathrm{L})$. The iron concentration ranged from 0.031 to $1.138 \mathrm{mg} / \mathrm{L}$, with the highest average concentration in the Geshgash River $(0.287 \pm 0.281 \mathrm{mg} / \mathrm{L})$. In all the rivers evaluated, the iron concentrations were higher than the national standards of the MINEN $(0.30 \mathrm{mg} / \mathrm{L})$ and those of the USEPA $(0.36 \mathrm{mg} / \mathrm{L})$. The zinc concentration ranged from 0.008 to $0.142 \mathrm{mg} / \mathrm{L}$, with the highest average concentration in the Capaco River $(0.071 \mathrm{mg} / \mathrm{L})$. The concentrations in all the rivers evaluated did not exceed the EQS for continental water $(1.00 \mathrm{mg} / \mathrm{L})$ destined for the extraction and cultivation of hydrobiological species. However, they exceeded the limit of the USEPA (2006) $(0.03 \mathrm{mg} / \mathrm{L})$. The copper concentration ranged from 0.002 to $0.127 \mathrm{mg} / \mathrm{L}$, with the highest average concentration in the Paraiso River $(0.043 \pm 0.032 \mathrm{mg} / \mathrm{L})$. However, no concentration of this metal recorded in all the rivers evaluated exceeded the EQS of the MINEN, category two, subcategory four, $(0.20 \mathrm{mg} / \mathrm{L})$. Nevertheless, the concentration of this metal widely exceeded the limits set by WHO $(0.003 \mathrm{mg} / \mathrm{L})$ and USEPA $(0.01 \mathrm{mg} / \mathrm{L})$. 
Table 2. Descriptive statistics of the concentration of heavy metals in river waters with aptitude for aquaculture assessed during 2011 2011-2013, in relation to national and international standards.

\begin{tabular}{|c|c|c|c|c|c|c|c|c|c|c|c|}
\hline $\begin{array}{c}\text { Metal } \\
(\mathrm{mg} / \mathrm{L})\end{array}$ & ED & Capaco & Casaracra & Geshgash & Pacchapata & Papahuay & Paraiso & Quinuacocha & Perú 2015 & $\begin{array}{c}\text { USEPA } \\
2006\end{array}$ & $\begin{array}{c}\text { WHO } \\
2011\end{array}$ \\
\hline \multirow{3}{*}{ Arsenic } & Range & $0.016-0.056$ & $0.008-0.046$ & $0.015-0.053$ & $0.005-0.042$ & $0.004-0.047$ & $0.011-0.064$ & $0.008-0.047$ & 0.10 & 0.34 & 0.01 \\
\hline & Average & 0.032 & 0.028 & 0.029 & 0.025 & 0.027 & 0.032 & 0.028 & & & \\
\hline & S.D & 0.009 & 0.012 & 0.010 & 0.010 & 0.011 & 0.012 & 0.013 & & & \\
\hline \multirow{3}{*}{ Lead } & Range & $0.024-0.098$ & $0.015-0.105$ & $0.019-0.054$ & $0.017-0.058$ & $0.008-0.056$ & $0.008-0.102$ & $0.013-0.061$ & 0.0025 & 0.01 & 0.003 \\
\hline & Average & 0.043 & 0.035 & 0.033 & 0.033 & 0.030 & 0.036 & 0.036 & & & \\
\hline & S.D & 0.021 & 0.018 & 0.011 & 0.011 & 0.011 & 0.020 & 0.012 & & & \\
\hline \multirow{3}{*}{ Iron } & Range & $0.053-0.423$ & $0.046-1.003$ & $0.071-1.138$ & $0.051-1.112$ & $0.035-0.322$ & $0.046-1.068$ & $0.031-0.492$ & 0.30 & 0.36 & --- \\
\hline & Average & 0.168 & 0.226 & 0.287 & 0.181 & 0.131 & 0.226 & 0.179 & & & \\
\hline & S.D & 0.096 & 0.214 & 0.281 & 0.211 & 0.071 & 0.238 & 0.129 & & & \\
\hline \multirow{3}{*}{ Zinc } & Range & $0.037-0.137$ & $0.033-0.142$ & $0.008-0.109$ & $0.015-0.122$ & $0.015-0.108$ & $0.014-0.106$ & $0.014-0.123$ & 1.00 & 0.03 & --- \\
\hline & Average & 0.071 & 0.067 & 0.049 & 0.053 & 0.064 & 0.056 & 0.052 & & & \\
\hline & S.D & 0.028 & 0.031 & 0.028 & 0.028 & 0.028 & 0.027 & 0.023 & & & \\
\hline \multirow{3}{*}{ Copper } & Range & $0.002-0.088$ & $0.005-0.072$ & $0.008-0.095$ & $0.005-0.041$ & $0.009-0.105$ & $0.007-0.127$ & $0.015-0.115$ & 0.20 & 0.01 & 0.003 \\
\hline & Average & 0.034 & 0.030 & 0.033 & 0.018 & 0.030 & 0.043 & 0.036 & & & \\
\hline & S.D & 0.022 & 0.019 & 0.020 & 0.009 & 0.021 & 0.032 & 0.022 & & & \\
\hline
\end{tabular}


The results obtained are supported by Singh et al. (2014), who report that aquatic organisms are exposed to various contaminants either through the water or the food they ingest. However, the uptake of heavy metals will depend on the total concentration and bioavailability of the metal, as well as physiological factors. Other research supporting the results indicate that concentrations of metals in fish organs depend on the actual level of contamination of the water they inhabit, and accumulation of metals in tissues may indicate levels of real metals in their environment (Poleksic et al., 2010; Jia et al., 2018).

\subsubsection{Cluster Analysis}

Custer analysis is a commonly used approach where clusters are formed sequentially starting with the most similar pair of objects and forming higher clusters step-by-step, and that the Euclidean distance usually gives similarities between two samples, and "distance" can be represented by the "difference" between the analytical values of both samples (Rencher, 2005). Cluster analysis was used to detect a group of rivers that had similar characteristics (spatial variability) and identify rivers with pollution problems (Tsai et al., 2016). Cluster analysis was performed based on the Bray and Curtis Index (1957) to detect groups of rivers evaluated that had similar characteristics and that have been affected by similar concentrations of potentially toxic metals. The hierarchical grouping of the rivers evaluated using the Ward method with the square Euclidean distance gave rise to a dendrogram made up of two clusters with minimal difference. The first cluster is formed by the Capaco, Papahuay and Paraíso Rivers, and the second by the Casaracra, Geshgash, Pacchapata and Quinuacocha Rivers (Figure 2).

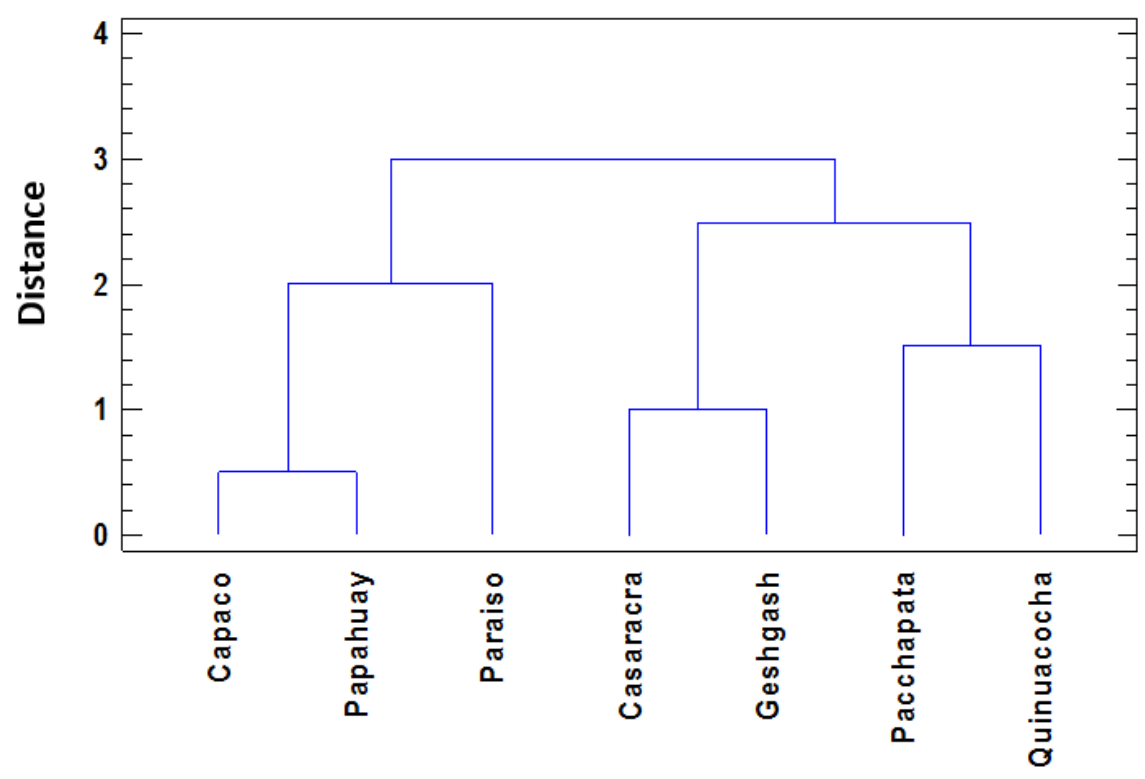

Figure 2. Dendrogram of similarity among rivers with aptitude for aquaculture according to the concentrations of heavy metals.

\subsubsection{Principal component analysis}

The results of the PCA are shown in Table 3 where the information of the components is summarized during the two sampling periods. In rainy season, the first two components absorb $53.53 \%$ of the variance of the PCA with eigenvalues greater than 1. Component 1 explains $28.92 \%$ of the total variance and Component 2 of $24.61 \%$. In the dry season, three components were explained by $73.69 \%$ of the variance of the PCA, with eigenvalues greater than 1 . In Component 1, there are moderate loads for arsenic that explains the variance of $30.96 \%$; in Component 2, there is a strong load for zinc and relatively low loads for iron; and in Component 
3 , there is a moderate load for iron. Therefore, the positive values of each component are related to important inputs, and the negative values correspond to low inputs (Barakat et al., 2016).

Table 3. PCA values and percentage of the variance of the main components and the relation of the variables, according to the sampling period.

\begin{tabular}{lccc}
\hline \multirow{2}{*}{ Variables } & \multicolumn{3}{c}{ Components } \\
\cline { 2 - 4 } & $\mathbf{1}$ & $\mathbf{2}$ & $\mathbf{3}$ \\
\hline Rainy season & & & \\
\hline $\mathrm{Cu}$ & 0.540 & -0.466 \\
$\mathrm{Zn}$ & 0.113 & -0.777 & \\
$\mathrm{Fe}$ & 0.320 & 0.177 & \\
$\mathrm{~Pb}$ & 0.513 & 0.155 & \\
$\mathrm{As}$ & 0.575 & 0.353 & \\
Own values & 1.45 & 1.23 & \\
$\%$ total variance & 28.92 & 24.61 & \\
$\%$ comulative variance & 28.92 & 53.53 & \\
\hline Drought season & & & \\
\hline $\mathrm{Cu}$ & 0.403 & 0.158 & 0.546 \\
$\mathrm{Zn}$ & -0.207 & $\mathbf{0 . 8 4 4}$ & 0.101 \\
$\mathrm{Fe}$ & -0.417 & -0.457 & 0.613 \\
$\mathrm{~Pb}$ & 0.435 & 0.119 & 0.504 \\
$\mathrm{As}$ & 0.657 & -0.199 & -0.247 \\
$\mathrm{Own}$ values & 1.55 & 1.14 & 1.00 \\
$\%$ total variance & 30.96 & 22.72 & 20.01 \\
$\%$ cumulative variance & 30.96 & 53.68 & 73.69 \\
\hline
\end{tabular}

\subsubsection{Discriminant Analysis}

This statistical method is designed to develop a set of discrimination functions which can help to differentiate between factors (rainy season and dry season) due to the use of quantitative variables. A total of 138 cases were used to develop a model that discriminates between the rainy and dry season. Using the forward- and backward-selection algorithm, it was determined that two of the five variables were significant predictors of the time, in this case, copper and lead are sufficient to discriminate the variables between the rainy season or the dry season. The discriminant function is statistically significant with a confidence level of 95.0\% (Table 4).

Table 4. Coefficients of the discriminant analysis of the temporal variation of the water quality of lotic systems with aptitude for aquaculture at the watershed of the Mantaro River.

\begin{tabular}{lcccccc}
\hline \multirow{2}{*}{ Variables } & \multicolumn{2}{c}{ All variables } & \multicolumn{2}{c}{$\begin{array}{c}\text { Step-by-step forward } \\
\text { selection }\end{array}$} & \multicolumn{2}{c}{$\begin{array}{c}\text { Step-by-step backward } \\
\text { selection }\end{array}$} \\
\cline { 2 - 7 } & Rain & Drought & Rain & Drought & Rain & Drought \\
\hline $\mathrm{Cu}$ & 63.337 & -1.225 & 160.361 & 97.666 & 160.361 & 97.666 \\
$\mathrm{Zn}$ & 103.882 & 108.985 & & & & \\
$\mathrm{Fe}$ & 22.276 & 19.592 & & & & \\
$\mathrm{~Pb}$ & 261.243 & 219.613 & 285.258 & 246.113 & 285.258 & 246.113 \\
$\mathrm{As}$ & 239.044 & 247.354 & & & & \\
Constant & -15.15 & -12.00 & -8.67 & -5.57 & -8.67 & -5.57 \\
\hline
\end{tabular}


Of the 138 observations used to adjust the model, 97 (70.29\%) of the total observations were correctly classified by the forward- and backward-step methods. While if we consider all the variables we obtain that $102(73.91 \%)$ of the data were correctly classified (Table 5).

Table 5. Classification matrix for the discriminant analysis of the temporal variation of the water quality of lotic systems with aptitude for aquaculture at the watershed of the Mantaro River.

\begin{tabular}{lccc}
\hline \multirow{2}{*}{ Rainy season } & \% accurate & \multicolumn{2}{c}{ Season assigned by the DA } \\
\cline { 3 - 4 } & & Rain & Drought \\
\hline All variables & & \\
\hline Rain & 68.75 & 44 & 20 \\
Drought & 78.38 & 16 & 58 \\
Total & 73.91 & 60 & 78 \\
\hline Step-by-step forward selection & & \\
\hline Rain & 68.75 & 44 & 20 \\
Drought & 71.62 & 21 & 53 \\
Total & 70.29 & 65 & 73 \\
\hline Step-by-step backward selection & & \\
\hline Rain & 68.75 & 44 & 20 \\
Drought & 71.62 & 21 & 53 \\
Total & 70.29 & 65 & 73 \\
\hline
\end{tabular}

Figure 3 shows the discriminant parameters recognized by DA related to the sampling times. The average concentration of $\mathrm{Zn}$ was slightly lower in the rainy season $\left(5.10 \times 10^{-02}\right)$ than in the dry season $\left(5.34 \times 10^{-02}\right)$. For $\mathrm{Cu}$, the average concentration was higher in the rainy season $\left(3.68 \times 10^{-04}\right)$ than in the dry season $\left(1.19 \times 10^{-04}\right)$ showing a marked effect on the sampling period. For the Fe, there was no marked effect with respect to the sampling period, where averages of $1.43 \times 10^{-01}$ were found for the rainy season and $1.28 \times 10^{-01}$ for the dry season. The average concentration of $\mathrm{Pb}$ had averages of $3.59 \times 10^{-02}$ and $3.10 \times 10^{-02}$ for the rainy and dry season, respectively; and, finally, the concentration of As, following the same pattern as $\mathrm{Cu}, \mathrm{Fe}$ and $\mathrm{Pb}$, were greater in the rainy season than in the dry season $\left(3.00 \times 10^{-02}\right.$ facing $2.66 \times 10^{-02}$ ). The lower concentration of $\mathrm{Zn}$ during the rainy season would be due to the dilution effect of water (Mohiuddin et al., 2012; Islam et al., 2015). Meanwhile, the highest concentrations $\mathrm{Cu}, \mathrm{Fe}, \mathrm{Pb}$ and $\mathrm{As}$ would be related to the influence of mining activity in the area (Kapia et al., 2016).

\section{CONCLUSIONS}

The results show that in the seven rivers evaluated the average concentration of $\mathrm{Pb}, \mathrm{Fe}$ and $\mathrm{Cu}$ exceeded the quality standards of Peru's continental water for the extraction and cultivation of hydrobiological species and USEPA standards for the protection of fish and aquatic life. The average concentration of $\mathrm{Zn}$ only exceeded USEPA standards, while the concentrations of $\mathrm{Pb}$ and $\mathrm{Cu}$ also surpassed those of the WHO.

The cluster analysis suggests that the rivers evaluated, in which the fish farming activity is intensively developed, have similar characteristics in relation to the concentration of heavy metals. According to the analysis of main components, in Component 1 , there are moderate loads for arsenic; in Component 2, there is a strong load for zinc and relatively low loads for iron; and, in Component 3, there is a moderate charge for iron. The discriminant analysis 
revealed that two of the five variables were significant predictors of the season in this case, copper and lead were sufficient to discriminate the variables between the rainy or dry season.

(a)

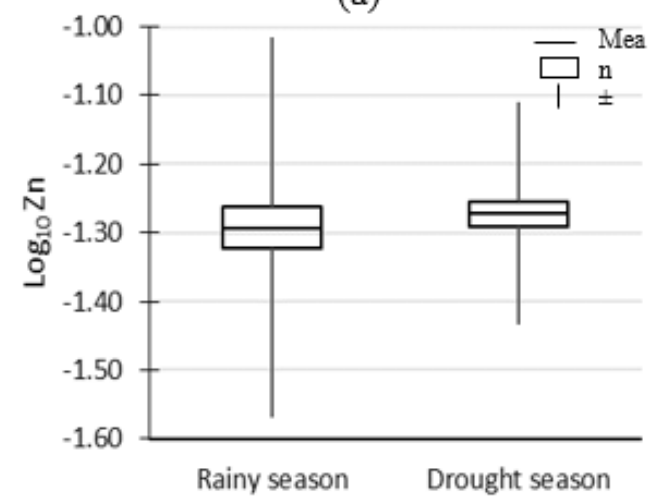

(c)

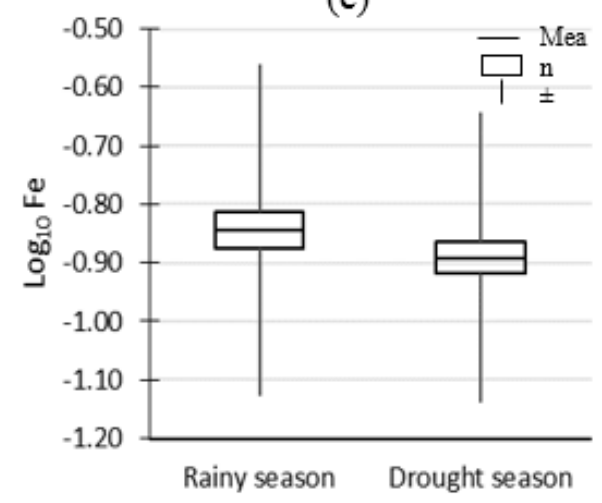

(b)

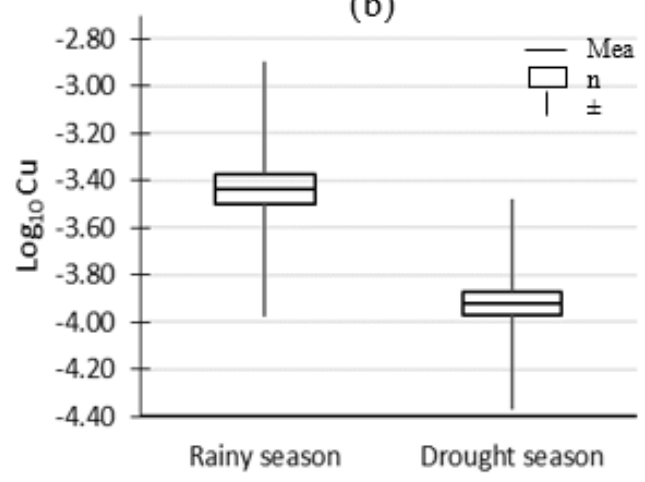

(d)

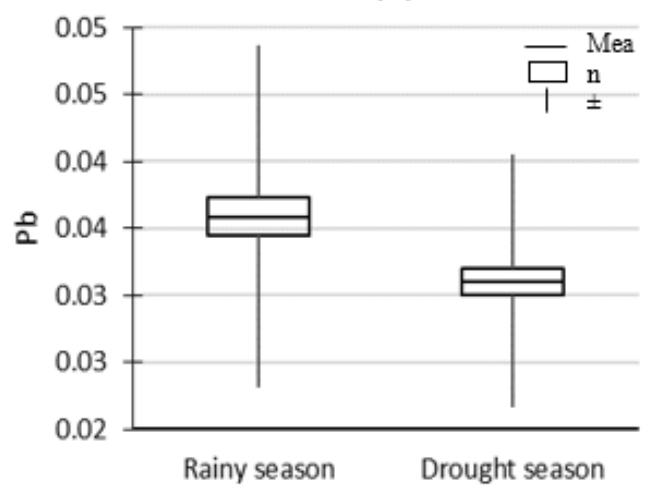

(e)

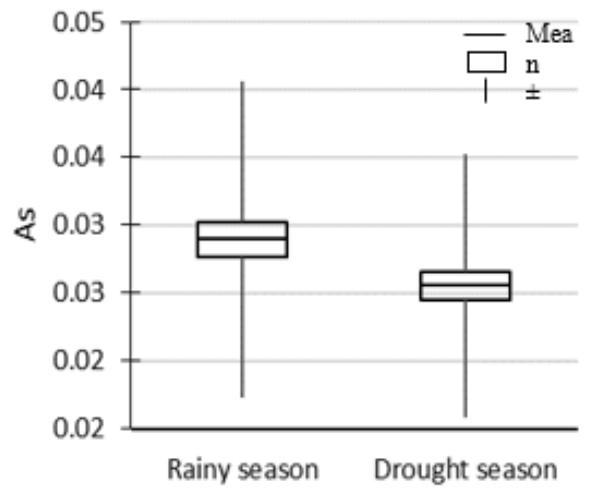

Figure 3. Temporal variability of heavy metals in river waters with aptitude for aquaculture, assessed during 2011-2013.

\section{REFERENCES}

APHA; AWWA; WEF. Standard Methods for the Examination of Water and Wastewater. $22^{\text {nd }}$ ed. Washington, D.C., 2012. 541 p.

BARAKAT, A.; EL BAGHDADI, M.; RAIS, J.; AGHEZZAF, B.; SLASSI, M. Assessment of spatial and seasonal water quality variation of Oum Er Rbia River (Morocco) using multivariate statistical techniques. International Soil and Water Conservation Research, v. 4, n. 4, p. 284-292, 2016. https://doi.org/10.1016/j.iswcr.2016.11.002 
CHANAMÉ, F.; CUSTODIO, M.; PANTOJA, R.; UNCHUPAICO, I. Bioaccumulation of heavy metals in Oncorhynchus mykiss for export at production centers in the Peruvian Central Highlands. Revista Ambiente \& Agua, v. 12, n. 4, p. 527-542, 2017. http://dx.doi.org/10.4136/ambi-agua.2100

EVERITT, B. Cluster Analysis. Quality and Quantity, v. 14, n. 1, 1980. https://doi.org/10.1007/BF00154794

GUNATILAKE, S. K. Methods of Removing Heavy Metals from Industrial Wastewater. Journal of Multidisciplinary Engineering Science Studies, v. 1, n. 1, p. 12-18, 2015.

HECKLER, C. E. Applied Multivariate Statistical Analysis. Technometrics, v. 47, n. 4, p. 517 , 2005. https://doi.org/10.1198/tech.2005.s319

ISLAM, M. S.; AHMED, M. K.; RAKNUZZAMAN, M.; HABIBULLAH-AL-MAMUN, M.; MASUNAGA, S. Metal Speciation in Sediment and Their Bioaccumulation in Fish Species of Three Urban Rivers in Bangladesh. Archives of Environmental Contamination and Toxicology, v. 68, n. 1, p. 92-106, 2015. https://doi.org/10.1007/s00244-014-0079-6

JIA, Y.; WANG, L.; QU, Z.; YANG, Z. Distribution, contamination and accumulation of heavy metals in water, sediments, and freshwater shellfish from Liuyang River, Southern China. Environmental Science and Pollution Research, v. 25, n. 7, p. 7012-7020, 2018. https://doi.org/10.1007/s11356-017-1068-X

KAPIA, S.; RAO, B. K. R.; SAKULAS, H. Assessment of heavy metal pollution risks in Yonki Reservoir environmental matrices affected by gold mining activity. Environmental Monitoring and Assessment, v. 188, n. 10, 2016. https://doi.org/10.1007/s10661-0165604-9

KWOK, C. K.; LIANG, Y.; WANG, H.; DONG, Y. H.; LEUNG, S. Y.; WONG, M. H. Bioaccumulation of heavy metals in fish and Ardeid at Pearl River Estuary, China. Ecotoxicology and Environmental Safety, v. 106, p. 62-67. 2014, https://doi.org/10.1016/j.ecoenv.2014.04.016

MOHIUDDIN, K. M.; OTOMO, K.; OGAWA, Y.; HIKAZONO, N. Seasonal and spatial distribution of trace elements in the water and sediments of the Tsurumi River in Japan. Environmental Monitoring and Assessment, v. 184, n. 1, p. 265-279, 2012. https://doi.org/10.1007/s10661-011-1966-1

MUNAVALLI, G. R.; MOHAN KUMAR, M. S. Water quality parameter estimation in a distribution system under dynamic state. Water Research, v. 39, n. 18, p. 4287-4298, 2005. https://doi.org/10.1016/j.watres.2005.07.043

NAUEN, C. E. Compilation of legal limits for hazardous substances in fish and fishery product. Roma: FAO, 1983. 102 p. (FAO Fish. Circ, 764).

PERÚ. Ministerio del Ambiente. Decreto Supremo N 015-2015-MINAM. El Peruano, 19 dic. 2015. Available en: http://www.minam.gob.pe/wp-content/uploads/2015/12/DecretoSupremo-Nº-015-2015-MINEN.pdf. Access: Dec. 2018.

POLEKSIC, V.; LENHARDT, M.; JARIC, I.; DJORDJEVIC, D.; GACIC, Z.; CVIJANOVIC, G. et al. Liver, gills, and skin histopathology and heavy metal content of the danube sterlet (Acipenser ruthenus Linnaeus, 1758). Environmental Toxicology and Chemistry, v. 29, n. 3, p. 515-521. 2010. https://doi.org/10.1002/etc.82 
RENCHER, A. C. A review of "Methods of Multivariate Analysis, Second Edition" IIE $\begin{array}{llllll}\text { Transactions, } & \text { v. } 37, \quad \text { n. } & 11, & \text { p. }\end{array}$ 2005.https://doi.org/10.1080/07408170500232784

ŞENER, Ş.; ŞENER, E.; DAVRAZ, A. Evaluation of water quality using water quality index (WQI) method and GIS in Aksu River (SW-Turkey). Science of the Total Environment, n. 584-585, p. 131-144, 2017. https://doi.org/10.1016/j.scitotenv.2017.01.102

SINGH, A. K.; SRIVASTAVA, S. C.; VERMA, P.; ANSARI, A.; VERMA, A. Hazard assessment of metals in invasive fish species of the Yamuna River, India in relation to bioaccumulation factor and exposure concentration for human health implications. Environmental Monitoring and Assessment, v. 186, n. 6, p. 3823-3836, 2014. https://doi.org/10.1007/s10661-014-3660-6

TSAI, Y. C.; CHUNG, C. Y.; CHUNG, C. C.; GAU, H. S.; LAI, W. L.; LIAO, S. W. The Impact of Typhoon Morakot on Heavy Metals of Dapeng Bay and Pollution from Neighboring Rivers. Environmental Modeling and Assessment, v. 21, n. 4, p. 479-487, 2016. https://doi.org/10.1007/s10666-015-9474-2

TYAGI, S.; SHARMA, B.; SINGH, P.; DOBHAL, R. Water Quality Assessment in Terms of Water Quality Index. American Journal of Water Resources, v. 1, n. 3, p. 34-38, 2013. https://doi.org/10.12691/ajwr-1-3-3

UNITED STATES. Environment Protect Agency - USEPA. National recommended water quality criteria. Washington, 2006. $21 \mathrm{p}$.

WASEEM, A.; ARSHAD, J.; IQBAL, F.; SAJJAD, A.; MEHMOOD, Z.; MURTAZA, G. Pollution Status of Pakistan: A Retrospective Review on Heavy Metal Contamination of Water, Soil, and Vegetables. BioMed Research International, v. 2014, 29 p., 2014. https://doi.org/10.1155/2014/813206

WORLD HEALTH ORGANIZATION - WHO. Guidelines for drinking-water quality. 4th ed. Amita Bhaduri, 2011. 564 p.

WRONSKI, T.; DUSABE, M. C.; APIO, A.; HAUSDORF, B.; ALBRECHT, C. Biological assessment of water quality and biodiversity in Rwandan Rivers draining into Lake Kivu. Aquatic Ecology, v. 49, n. 3, p. 309-320, 2015. https://doi.org/10.1007/s10452-0159525-4

ZUBIETA, R.; SAAVEDRA, M.; SILVA, Y.; GIRÁLDEZ, L. Spatial analysis and temporal trends of daily precipitation concentration in the Mantaro River basin: central Andes of Peru. Stochastic Environmental Research and Risk Assessment, v. 56, n. 6, p. 13051318, 2017. https://doi.org/10.1007/s00477-016-1235-5 